\title{
Superpowers and the environment
}

Eric Ashby

The Economic Superpowers and the Environment: the United States, the Soviet Union and Japan. By Donald R. Kelley, Kenneth R. Stunkel and Richard R. Wescott. Pp. viii 335. (Freeman: San Francisco, 1976.) Hardcover $\$ 11.95$; softcover $\$ 5.95$.

A BOOK on this topic was badly needed. The authors have met the need admirably. They modestly point out that their book is not a comparative study of environmental policies in the three superpowers, but is rather three profiles, one for each of the three nations they have chosen. They urge the reader to make his own comparisons and they make this easy for him by the arrangement of the book; for instead of dividing it into three sections, one for each country, they have divided the book into topics-the different kinds of environmental hazard, the attitude of the public toward the problems, the politics of environmental quality, and programs for the protection of the environment. Under each of these topics they discuss the recent history and the contemporary position in the US, the Soviet Union, and Japan.

Any reader familiar with the gush of doomsday literature in the past five years may be a little uneasy that the authors make some of this the starting point for their story, without reference to the criticism which has devalued some of this literature. But any unease is dispelled once the authors get down to the job they have set themselves. Their own exposition is clear, well documented, and on the whole free from those emotive adjectives which diminish the credibility of much writing about the environment. A feature which makes the book unusually interesting is the way the authors have put environmental problems into their historical and cultural and economic and political settings.

The first chapter describes an America, a Soviet Union, and a Japan which respected nature: the pastoral landscape celebrated by Jefferson, peopled by prudent farmers, conserving their heritage; the Slavophile closeness to nature, preached by Tolstoy; the exquisite harmony between man and nature in the Japan of Tokugawa. The book then goes on to give factual data about the degree of pollution (air, water, solid wastes, radioactivity, noise) in the three countries. Here they are up against the coyness of the Soviet Union in disclosing data comparable to that which the American Council on Environmental Quality issues each year; but they do present a remarkably useful set of facts, all the same.

It is a grim picture: neglect, in spite of the evident dangers in Japan (by far the most gravely injured country in consequence of its industrial development); indifference, due to the immense size of the Soviet Union (where the only measure of production which earned political approval was quantity, without regard to its second order effects); and frustration, in spite of the spate of legislation in the US and the vast sums being spent on environmental protection. All these countries face environmental problems which sooner or later are likely to lead to major social crises, best described as an obligation to change their cherished styles of life.

Japan is closest to the crisis, but her dilemma may be redeemed by the ageold tradition of "group co-operation, self-discipline" and the obedience which comes of "traditional subservience of nearly everyone to somebody else." She has changed her life style twice in the last century; she might be capable of doing it again.

America is (in the authors' opinion) going through a cyclical pattern of waxing and waning concern for the environment. When the National Environmental Policy Act was passed, cleaning up pollution came high in the public opinion polls; but the public assumed that once legislation was passed, all would be well, and the oil crisis swiftly eclipsed interest in protecting the environment; it left no doubt that Americans put a higher price tag on gasoline for their cars than on cleaner air in their cities.

The Soviet Union has the best chance of anticipating the dangers of exploiting the environment, because she is not so far along the road of exploitation. Moreover she does not need to woo public opinion nor to tame corporations in order to adapt their life style to a pattern which takes better care of the environment.

This sober, level-headed book concedes that Japan and the Soviet Union, with highly centralised government and traditions of obedience to authority, could more easily extricate themselves from the ecological trap into which industrialisation leads. But they end with a hopeful paradox: that the open society in the US, where public opinion counts for much more, may in the end be better equipped to sustain a long term adaptation to a world with too many people, too few resources, and limitations to the capacity of air and water to contain our wastes. Hanging over the story there is Heilbroner's threat: "who cares, in the perspective of environmental safety, if institutions of present-day capitalism and socialism disappear?"

Eric Ashby (Lord Ashby of Brandon) recently retired from the Mastership of Clare College, Cambridge. He was Chairman from 1970 to 1973 of the UK Royal Commission on Environmental Pollution.

\section{Insight marred by error}

The Biology of Population Growth. (Biology and Environment.) Robert L. Snyder. Pp. 227. (Croom Helm: London, April 1976.) £6.95.

THIs broadly-based account of population biology lays special emphasis on mammalian studies, with an American slant-Dr Snyder is director of a research laboratory at Philadelphia Zoo. Chapters deal with Ecology and Population, Reproduction, Mortality, Dispersion and Dispersal, Population Dynamics, Natural
Regulation, Compensatory Mechanisms, and Implications to Human Populations. The treatment is comprehensive in the sense that it touches at least briefly on most aspects of the subject. Some are dealt with in more detail, including the population cycles and reproductive physiology of mammals, the social stress theory of population regulation, experiments on the social organisation of captive mouse colonies, and Dr Snyder's own study of compensatory processes in populations of woodchucks. On this 